Archived version from NCDOCKS Institutional Repository http://libres.uncg.edu/ir/asu/

\author{
Appalachyan \\ воO

\section{Musée Gauguin Tahiti: Indigenous Places, Colonial Heritage}

\author{
By; Heather Waldroup
}

\begin{abstract}
This essay discusses the Musee Gauguin Tahiti as a problematic counterpoint for contemporary developments in Oceanic museology. Considering Gauguin's complex relationship to French colonial history, the tourism industry and Pacific Island history, the site raises a number of significant issues. It occupies an ambiguous place in the museum/cultural centre/heritage site taxonomy, and its undermining of standard museum display practices often results in obfuscation, rather than clarification, of viewer understanding of Gauguin 's artworks themselves, their art historical significance, or the artist's relationship to Pacific social history. Still, it offers a unique experience for touristvisitors, and has the potential to include indigenous communities in its display practices, programming and management. This essay engages with emerging literature in the field of Oceanic museum studies to consider the role of this curious historical site in the contemporary, global Pacific, particularly how it might more effectively address the needs of non-tourist (especially indigenous) communities.
\end{abstract}

Waldroup, Heather. (2008), Musée Gauguin Tahiti: Indigenous Places, Colonial Heritage.” International Journal of Heritage Studies 14:6, 489-505 (lead essay). Version of record published by Routledge - Taylor \& Francis (ISSN: 1470-3610). DOI: 10.1080/13527250802503258 
Paul Gauguin spent much of the last 12 years of his life in French Polynesia, arriving on Tahiti Nui in the summer of 1891. He died in 1903 on Hiva Oa in the Marquesas archipelago. While most of Gauguin's actual artworks now reside in museums and private collections in Europe and North America, his life and history are curiously represented at two sites in French Polynesia: the Musee Gauguin in Papeari district on Tahiti Nui and the Paul Gauguin Cultural Centre in the village of Atuona on Hiva Oa. Unlike the Western museums that own Gauguin originals, and display them in the style evoking the 'masterpiece' (hung against a solid background, displayed in a locked case, properly labelled, climate controlled, and guarded), the sites in Hiva Oa and Papeari, lacking extensive collections of original works of art, instead stress the value of their locations over the value of individual objects. In comparison with the hegemonic Western museum, with its suggestion of academic superiority and the unquestioned originality of its collection, the two sites in Polynesia present, instead, the embodied authenticity of experience: of Gauguin's experience and, by extension, the experience of the Western viewer. The Musee Gauguin and the Centre Culturel Paul Gauguin are 'exhibitionary complexes' of an especially peculiar sort. [1]

This essay focuses on one of these sites, the Musee Gauguin, and considers the way it might more effectively serve what has been its primary audience of tourist -visitors as well as begin to incorporate indigenous Pacific Islanders into its practices, programming and management. The Centre Culturel Paul Gauguin is already doing some of this: it holds residencies for Island artists and uses Marquesan language in its wall text. It is also better funded than the Musee and has had stronger and more consistent leadership. The Musee Gauguin, in contrast, has the feeling of a rather forgotten place, with outdated displays and an eclectic collection of historical objects. Still, the Musee does mobilise architecture, display practices and the discourse of the 'original' to some intriguing ends, offering a unique-if not fully satisfying--experience for the visitor. The Musee also engages with the popular, romantic-primitivist narrative of Gauguin, but its ultimate messages are something more ambiguous and ambivalent.

In primarily serving an audience of outsiders-often accommodating groups as part of longer, structured day-tour packages-the Musee Gauguin has the power to shape outsider knowledge of French Polynesia. Its location on the main island of French Polynesia is significant, as the majority of visitors who come to French Polynesia (an average of more than 18,000 per month in 2006) arrive on the island of Tahiti.[2] Comparatively few visitors are able to travel to the more remote archipelago of the Marquesas to visit the Centre Culturel Paul Gauguin. The Musee's geographical location is also noteworthy, considering Gauguin's role in contemporary Tahitian tourism. While Gauguin's artworks themselves are aesthetically complex, their reproduction (either outright, or through restaging with contemporary models) in tourist advertisements suggests that the paintings present an unmediated representation of French Polynesia and that French Polynesia has remained unchanged since the 1890s. Further, the reproduction of Gauguin's paintings for the purpose of advertising French Polynesia as a vacation destination suggests to tourists what they might find in French Polynesia. On the online virtual tour of the cruise ship Paul Gauguin, a reproduction of Gauguin's painting Arearea (1892) accompanies images of bourgeois, heterosexual couples relaxing, shopping and being entertained by Polynesians. The ship is staffed by 'Gauguines', young Polynesian women dressed in missionary-style dress, who serve as hostesses, tour guides and dancers. The site explains that 
'[the ship's] beloved troupe of Gauguines-part cruise staff, part entertainers, part storytellers-add the unique personality of French Polynesia to every cruise.,[3] Popular travel guides, including the Lonely Planet Tahiti and French Polynesia Travel Guide and Moon Tahiti, contain sections on Gauguin (the Moon Guide asks its readers, '[Are you] looking for details on Bora Bora's finest beaches or Gauguin's escape to the Marquesas? You'll find them in here').[4] In French Polynesia itself, postcard racks juxtapose reproductions of Gauguin's paintings with soft-erotic photographs of scantily clad Polynesian women on the beach. Indeed, the contemporary touristic appropriation of Gauguin's paintings plays a key role in the production of the 'tourist realism' of French Polynesia.[5] Jeremy MacClancy argues for the complexity and diversity of experiences, for both visitors and locals, that arise in tourist situations, but goes on to note that tourists' understandings of the culture they are visiting are often misconstrued: 'The common concept of authenticity held by almost all these wanderers is a mythical one grounded in a pretourist world, linked to ideas of unchanging cultures unaffected by the outside.,[6] While it is likely that tourists visiting the Musee Gauguin might arrive with similar beliefs about French Polynesia, supported by the appropriation of Gauguin's paintings for use in tourist advertisements, the Musee Gauguin could potentially counteract these exoticist discourses.

This essay engages with new literature in the field of Oceanic museology to consider the role that this institution might potentially occupy in the contemporary, global Pacific. This essay also suggests ways this site might serve as an analogue, in an international context, for the responsibility of similar sites to indigenous communities. Considering Gauguin's complex relationship to colonial history, the tourism industry and Pacific Island social history, the Musee Gauguin demonstrates especially distinct entanglements with global capitalism and suggests possibilities for institutions with even overtly colonial origins to dynamically represent history and articulate with nontourist communities in meaningful and significant ways. Certainly visitor response to museum displays is not a monolithic experience. This discussion focuses on display practice, architecture and the labelling of objects at the Musee in order to analyse the visual-aesthetic languages through which the institution speaks to its visitors. This essay considers the various ways audiences might read these displays, and the ways these existing formats for display might be expanded to address a wider variety of audiences.

\section{VISITING THE MUSEE GAUGUIN TAHITI}

The Musee Gauguin is relatively isolated in spite of its location on the main island of French Polynesia. It is situated in Papeari district, on the south coast of Tahiti Nui, where Gauguin never actually lived, but it is near Mataiea district, where Gauguin lived from September 1891 until leaving the island for the first time in June 1893. Built and opened in 1964 by the Foundation Singer-Polignac, a private French entity, on land acquired through a benefactor, the Musee Gauguin was intended to be a 'memorial of admiration and reverence' for the artist[7]. Some circle-island tours and Elder Hostel groups stop there, but the expensive taxi ride or long trip by public bus makes it difficult to access for independent visitors without cars of their own. The Musee Gauguin site is composed of several separate buildings, linked by covered walkways; the architecture of the site is an eclectic mixture of pan-Asian and Melanesian styles. 
The Musee's collection includes a broad range of items: some original artworks, reproductions of Gauguin's artwork (mostly colour photocopies on foam core backings) and historical objects, such as a top hat and a Breton menhir stone.

A visit to the Musee Gauguin is an intriguing, if not entirely illuminating, experience. The complex of buildings is located along a stretch of lagoon with views of the west coast of Tahiti Iti (connected to the main island, Tahiti Nui, by a narrow isthmus), next to a botanical garden; the landscaping is notable in itself. After paying a nominal admission fee and visiting the modest bookshop, the visitor is free to wander among the several buildings containing the Musee's exhibition displays and view the exhibits. The exhibition rooms are organised both chronologically and thematically. The visitor progresses through these rooms as he or she moves from building to building; as the buildings are connected by covered walkways, the direction of movement through them is fairly structured. The first room begins with a map of Gauguin's travels, an effective way to orient the viewer to Gauguin's life and to stress the theme of travel in his work. In this first building, the viewer is also introduced, through diorama-like displays of various illustrative objects, to Gauguin's childhood in Peru and his later life in France. The displays in the next few buildings focus on Gauguin's life in Tahiti and the Marquesas Islands, including well-made reproductions of the carved exterior panels from his house in Marquesas (the originals are now in the Musee D'Orsay), and a small model of the house itself. The final building contains photographic reproductions of Gauguin's paintings and a display focusing on the diffusion of Gauguin's paintings in collections throughout the world. Some displays are labelled in English, others are in French and others still are in both languages. In addition to the exhibition buildings, there is a small library and an artisanal market selling local arts, such as hand-dyed pareu and shell jewellery, on the site.

Various aspects of the Musee's display tactics make it difficult for a visitor without extensive prior knowledge of Gauguin, or significant experience with critically viewing collections, to walk away with a clear understanding of the artist's history. The museum is understaffed, with no guides or docents to lead the viewer through the displays. In most cases, the objects on display were not actually owned by the artist but are meant to be illustrative of his historical period; however, this is not always evident to the casual visitor. The labelling practices at the Musee are particularly fraught and often obscure, rather than illuminate, the objects' meaning, their relationship to Gauguin or their place within the overall display programme of the Musee. The inconsistency of the languages used in the labelling contributes to this. Small, older placards are written only in French; larger, newer, more detailed ones are only in English; in the latter sections of the display, the wall text is again only in French. Depending on the visitor's language abilities, that the languages are not translated can add to the confounded feel of the collection.[8] In other instances, translations are provided, but these are not clearly written. In the garden, placards in English and French are positioned beside several stone tikis from Raivavae in the Austral archipelago of French Polynesia (Figure 1). Originally in another museum, the tikis were transferred to the Musee Gauguin in 1965. The English translation explains that the presence of the tikis at the Musee 'gave place to new superstitious manifestations.' The obscurity of this statement is likely the result of an awkward translation, lending to the sense of confusion experienced by the English-speaking visitor who cannot read the accompanying French. While the tikis serve as representations of the Oceanic artworks that 
originally inspired Gauguin through their formal and cultural elements, describing their presence as '[giving] place to new superstitious manifestations' does not clarify their intended role as part of the Musee's collection.

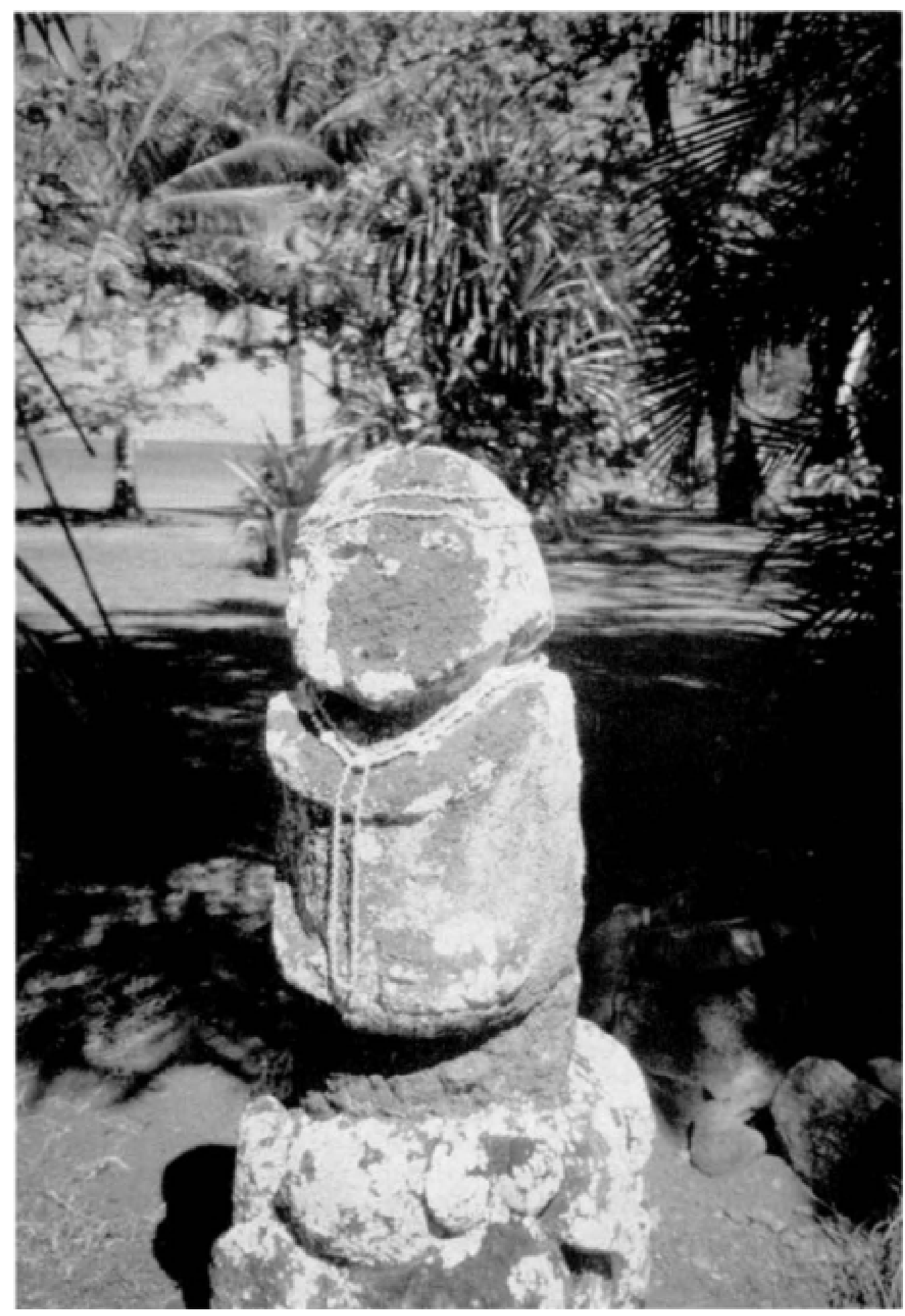

Figure 1 Tiki on display at the Musee Gauguin Tahiti. Source: H. Waldroup. 
The built environment of the Musee also does not clearly situate Gauguin's-or the visitor'sexperience within French Polynesian culture or history. While unique, the architectural style employed at the site is quite hybrid, lending to an overall sense of disarray. A publication in English on the Musee explains, 'the Foundation wanted a calm setting for its museum, away from the island's capital with its noisy festivals and the bustle of tourism and night life. Nor must there ever be a possibility, later, of unsuitable neighbors moving in to disturb the atmosphere of peace and 'contemplation' essential to the proposed museum.'[9] (What neighbours would, exactly, constitute an 'unsuitable' population is not made clear, but this statement furthers the idea of the Musee as a site intended only for certain 'suitable' visitors.) The architecture of the buildings is 'in no respect imitative'; according to the publication, architect Claude J. Bach 'hit on a style that is at once very modern in its use of materials, yet classical in the rational and balanced flow of its lines.' [10] Most rooms are open-air, although a climate-controlled building was added in 1976, facilitating the exhibition of original artworks. The overall architectural style is best described as 'pan-Asian', with low, gently sloping roofs with extended ornaments and exposed beams (Figure 2). One structure with a tall, sloping roof does bear some resemblance to the Tamberan men's houses of the Abelam culture of Papua New Guinea (Figure 3). In general, however, the architecture is not overtly Polynesian in style; while the site is idyllic and visually intriguing, in the end the amalgamation of architectural styles and decorative elements draws the visitor further from a clear understanding of Gauguin's relationship to Polynesian art and culture. Neither Polynesian nor European, the buildings do not provide the visitor with coherent signifiers of the artist or his experience in the Islands. 


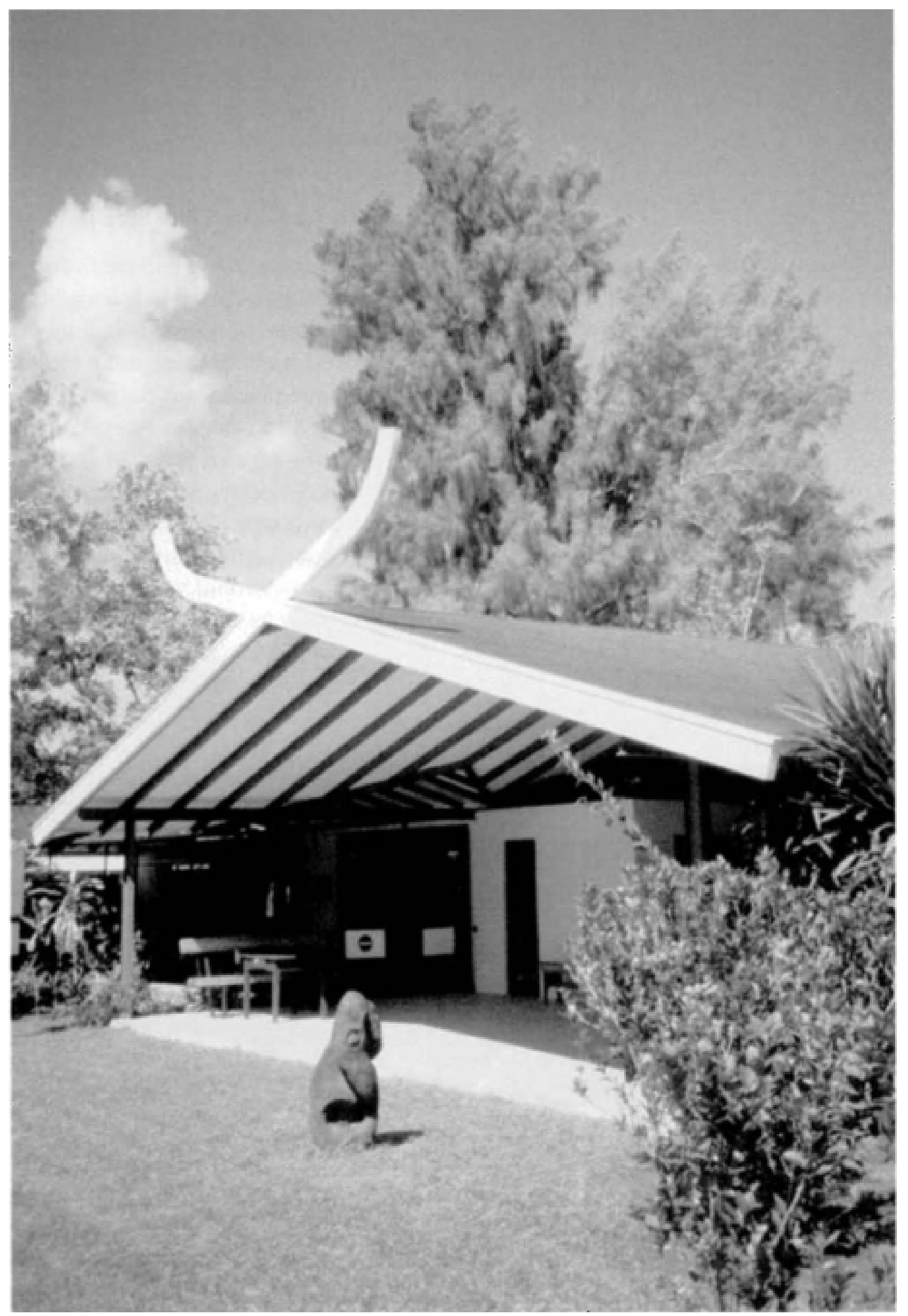

Figrure 2 Musee Gauguin Tahiti. This building houses the library. Source: H. Waldroup. 


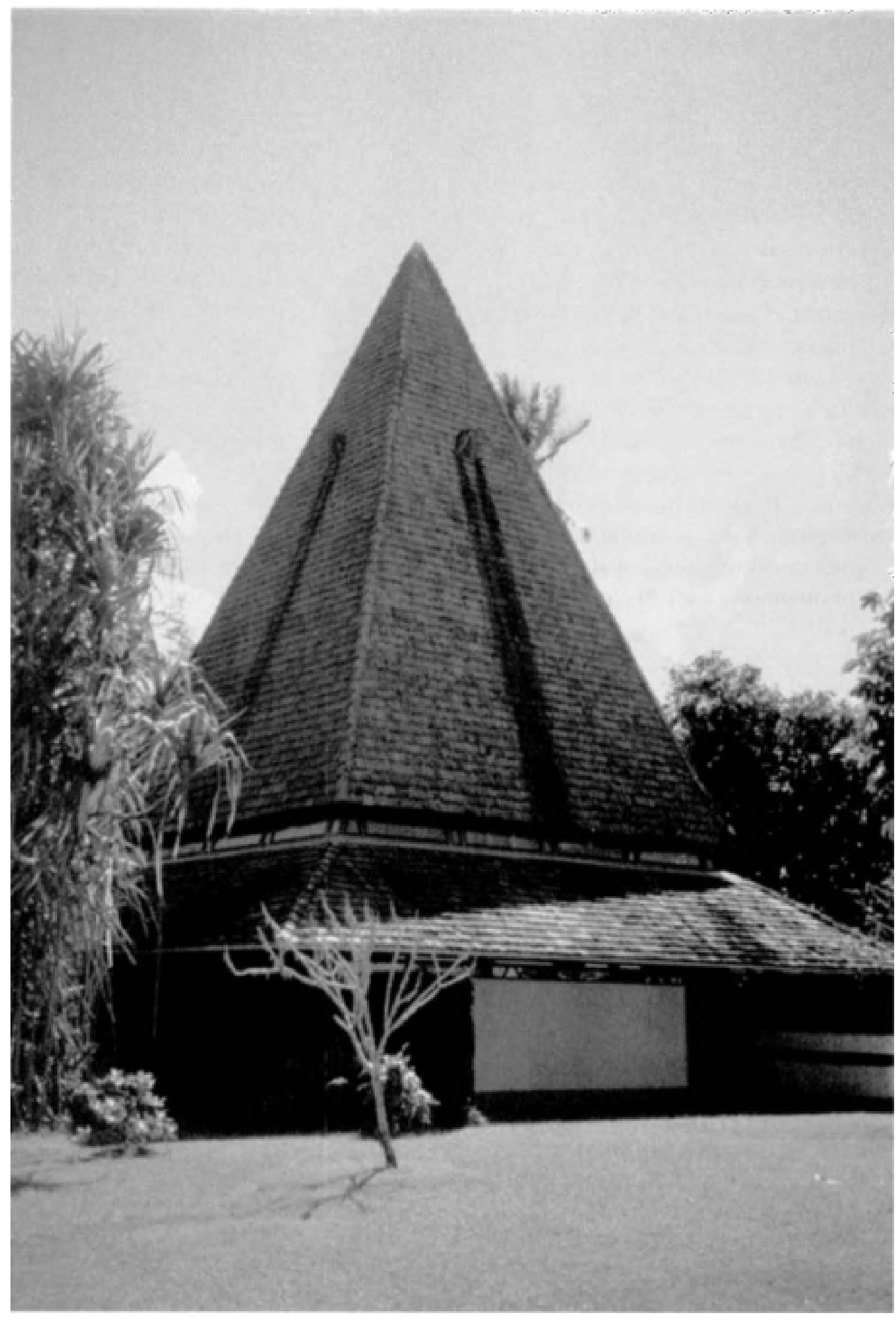

Figure 3 Musee Gauguin Tahiti. This building recalls Tamberan men's houses of the Abelam culture of Papua New Guinea. Source: H. Waldroup. 
Overall, the Musee Gauguin's anachronistic feel can be directly attributed to a lack of strong leadership in the institution: since the former director, Gilles Artur, passed away, the Musee has come under the umbrella of the Ministry of Culture, but has not retained a directorship position. [11] The Musee thus falls short of its intended goal-to honour Gauguin's life and artistic production, especially while he was in Polynesia-as the viewer does not necessarily walk away with a clear understanding of either of these. Its permanent exhibits have not been updated for some time, and the various and inconsistent languages used in the labelling does not allow for full understanding of the displays by visitors who know only French or only English, and indeed suggests the lack of a clearly determined audience. Its geographic location has a questionable relationship to Gauguin's history: unlike Hiva Oa (where the Centre Culturel Paul Gauguin is located), which possesses Gauguin's interred remains and a replica of his house, the Musee Gauguin site is not in an actual place of Gauguin's habitation. The remote location, away from the capital city, also removes it from easy access by tourists, and the lack of representation of indigenous culture, historical or contemporary, fails to integrate the local community. All of these result in a deficiency of income from admissions fees, private donations and state funding sources. A comment in the guestbook from a Papeete visitor, critiquing the English focus of many of the labels and noting that the space should be for the honour of Gauguin and not for American tourists, speaks to the overall sensation that the Musee does not live up to its potential functions, particularly for local audiences. However, I would add to this visitor's concern that the Musee's displays would not significantly enrich any preconceived understandings of Gauguin or his paintings by American tourists either.

\section{PAUL GAUGUIN AND PACIFIC LOCATIONS}

My position that this site has the potential to reach indigenous audiences, in spite of its original goal of memorialising a settler-colonial artist, draws on new directions in Gauguin scholarship as well as recent developments in Oceanic museology. While there is a long history of art historical scholarship on Gauguin in the West, it is only within the last few decades that scholars have argued for a more reciprocal relationship between Gauguin and Polynesian art and culture, and that Gauguin does occupy a place-however fraught-within Pacific social history. Gauguin was aesthetically influenced by the French Polynesian (especially Marquesan) art he encountered; additionally, there is strong evidence that he had at least some understanding of Polynesian culture, religion and language, and he was also influenced by the commercial photography industry in Tahiti.[12] Tahitian activist Chantal Spitz Wlites of the responses to her own enquiries into the artist, 'Paul Gauguin .... Les rejlexions des quelques amis a qui j'ai parle de ma presente intervention se resument li "tu t'interesses a ce pedophile main tenant?" Ou "c'etait un degenere" ou "j'espere que tu vas dire que c'etait un sale raciste" au encore "il a eu une vie de debauche. ",[13] In the same publication, however, Riccardo Pineri intriguingly argues that Gauguin's work, and its reception, occupies a 'double horizon. .. entre la tradition culturelle occidentale et la perception de l'oeuvre de l'artiste de la part de la culture polynesienne. '[14] Not all of these authors are in agreement as to the exact degree of Gauguin's understanding of Polynesian culture or his influence on contemporary Polynesian life, yet all would acknowledge that, for whatever reason, Gauguin's presence cannot be ignored in contemporary Polynesia. 
My own work has argued that Gauguin's paintings from French Polynesia have furthered the popular discourse I have termed elsewhere 'Polynesianism', with its accompanying antibourgeois, neoprimitivist fantasies of escape to the tropics.[15] In this way, Gauguin's paintings have taken on a variety of social and historical roles, many of which exist outside the boundaries of Gauguin's original avant-garde, primitivist aesthetic project. The paintings are records of French colonial presence in the Pacific, part of a vast archive of Western fantasies about life and people in the tropics. If read against the grain, however, they can reveal some aspects of indigenous response to Western presence, and as much as they have shaped (and continue to shape) a Western imaginary of Polynesia, they have played a role in indigenous artists' response to this history of colonialist primitivism and exoticism.[16] With some transfom1ations in its display tactics, the Musee Gauguin could be poised to address this complex, intersecting history more accurately, and would therefore provide a richer account of both Gauguin's history and indigenous history for various audiences.

The Musee Gauguin's more problematic aspects could be addressed through greater engagement with contemporary developments in indigenous museology in Oceania. Museums in the region have undergone significant transformation in the past 30 years. [17] Some national, previously colonial institutions are moving towards a more collaborative model of practice, and indigenous communities, including but not limited to now-independent nations, are creating their own spaces to honour, display, and uphold their culture. Alongside this movement, fully indigenous-controlled cultural centres have become key sites for self-representation in local, regional and global contexts. These centres exist in a web of intersecting relationships: between community, government and educational leaders, development organisations, keepers of traditional knowledge and makers of traditional art forms, and contemporary artists.

As in much of the formerly (and currently) colonised world, the emergence of indigenous cultural centres in Oceania also is closely tied with anti-colonial politics and cultural renaissance movements. In an early work from Oceanic museology, Maori scholar and activist Sidney Moko Mead noted that, in their broad definition as sites to store and exhibit objects of cultural and historical value, museums have significant parallels in a number of Oceanic structures, such as the whare whakairo of Aotearoa New Zealand and various forms of men's houses in Melanesia. He argued that indigenous communities need to draw on these models, rather than Western prototypes, in developing museum-like structures. [18] This has primarily manifested in Oceania through the development of cultural centres. By its very definition, the cultural centre resists a conventional definition of a museum in the Western sense, as a site solely devoted to the permanent preservation of original objects. Instead, cultural centres seek the active integration of the community through programming, including performance-based exhibitions, and often employ display practices that subvert the Western convention of the decontextualised object presented for aesthetic appreciation and observation. What is 'collected' by the cultural centre also extends beyond 'art' or other material objects, and cultural centres acknowledge alternate models of custodianship: as 'Eseta Fusitu'a has noted, 'In Tonga museums are in fact the homes of the people. Cultural property is out in society and is used daily.' Fusitu'a suggests instead that indigenous institutions might consider their role as 'resource places' for knowledge production and retention, rather than the preservation of individual objects above all other goals. [19] The indigenous presence at the site can also incorporate the built environment, including 
architecture modelled after traditional sacred structures and the use of sacred land, both of which are demonstrated at the Centre Culturel Jean-Marie Tjibaou in New Caledonia. 'Culture' at the indigenous museums and cultural centres in the region is a dynamic, rather than static, entity, represented through the material and other products of the area's people.[20]

Based on its origins as a memorial for a settler-colonial artist and its development out of a private French organisation, the Musee Gauguin will not necessarily develop into an institution that is entirely devoted to indigenous art, culture and history.[21] Nevertheless, that cultural centres represent the future of indigenous museological practice in Oceania suggests the absolute need for all institutions in the region, including the Musee Gauguin, to acknowledge this important development by including indigenous audiences in their display practices, programming and leadership. Nor is it likely, given the complex politics around the collection and display of European 'fine art' of extremely high commercial value, that the Musee Gauguin will have the ability to acquire a significant collection of original Gauguin works and thus operate as a 'museum' in the Western sense. Therefore, the Musee Gauguin might be most effectively considered a 'heritage site', with the potential to develop display practices and programming that are meaningful for both locals and visitors. This is not to say that a simple name change is the solution to all the Musee's troubles, and certainly the Musee Gauguin is a 'heritage site' of a complicated sort, as it honours a Western artist rather than local heritage. Still, recent scholarship has pointed to the radical potential of heritage sites to actively engage both the past and the present. Barbara Kirshenblatt-Gimblett defines heritage as 'a mode of cultural production in the present that has recourse in the past'.[22] She addresses the relationship between place, object and display practice in sites and performances that attempt to represent 'heritage', and notes several possible outcomes of these representations. Depending on the mode of display used to represent self to audience, the 'heritage' that is produced might be a form of 'tourist realism', a highly mediated experience of 'heritage' produced solely to appeal to outsiders (and, I would add, to set understandings and preconceived notions of these outsiders). On the other hand, Kirshenblatt-Gimblett goes on to note, heritage sites have the potential to create entirely new understandings of places and their histories. Heritage is not located entirely in the past, and its representation does not need to be either; instead, institutions might choose to combine their presentations of the past with a strategic deployment of modernity.[23] Thus, heritage sites do not need to erase or misrepresent the past, including its more unpleasant elements, yet they may choose to address instead the way the past and the present are dynamically interconnected.[24]

\section{IMPLICATIONS: FOR FRENCH POLYNESIA AND ELSEWHERE}

Upon my most recent visit to the Musee, several original wood sculptures by Gauguin were on display, on loan from a private collector living in Tahiti. These included Three Spoons and an Umete bowl, both made around 1892 and inspired by Marquesan pieces circulating in Papeete in the 1890s. If allowed to continue on exhibit, the presence of these artworks could lend authority to the Musee as an institution, and their juxtaposition with works by contemporary artists in the same space suggests an intriguing aesthetic dialogue between past and present. 
Certainly the relationship of the Musee Gauguin to indigenous and indigenous-minded institutions is not straightforward or uncomplicated, as the site represents an artist from the colonial culture whose work has played a key role in the Western primitivist fantasy of Polynesia. [25] It is currently visited primarily by non-resident tourists, and focuses on Gauguin himself rather than the strong historical and contemporary articulations between the artist and Polynesian art and culture. Still, with some funding, but particularly with strong leadership, the Musee could be transformed into an institution that both informs visitors of the intersection of Gauguin's history with the history of art and culture in French Polynesia and serves as an exhibition site that incorporates indigenous audiences into its programming. If considered more broadly as a 'heritage site', Gauguin's personal narrative does not need to be the dominant one at the Musee Gauguin.

The Musee Gauguin's challenges are certainly extensive. Of course, the institution primarily needs strong leadership, additional funding and a clear mission for its future; these are significant needs, but they are not unattainable. Several key updates could increase revenues by encouraging a more broad-based visitor population. First, the Musee might foreground the visitor's experience with a discussion of the site's goals and intentions, particularly with regard to Gauguin's place in contemporary Polynesian heritage and culture. A visit to the Musee might ask the visitor to consider several questions: Why is it important to continue to represent Gauguin's history in Tahiti itself? How is his work not only a part of European art history? Through dialogue between wall text and display object, the curators might go on to specifically address these questions for the visitor. Further, the Musee's displays are especially dated. The associates of the Musee over the years have conjured an intriguing collection from an arbitrary series of indigenous and imported objects. Although this institution might not have funding for new acquisitions, by reconsidering the objects kept on display and systematising the labelling system, and incorporating French, English and Tahitian into all the wall text, the Musee might better engage with, and include, a variety of audiences.

In spite of a lack of funding, the Musee does have a significant resource in its climate-controlled room. That this room is already being used to house several original Gauguin works as well as contemporary art is encouraging, and the Musee Gauguin might consider expanding its role in this regard. Private collectors in Tahiti hold ample collections of both historical and contemporary art. With some improvements to security, the Musee could take advantage of its climate-controlled exhibition space to hold temporary exhibitions that directly engage local audiences and local art communities. Additionally, for the future the site might consider a role in the regional art world outside of French Polynesia. As the Musee de Tahiti et des Tles/Te Anavaharau is primarily focused on French Polynesian cultural and natural history, the Musee Gauguin might employ its location on the main island of a major archipelago in the region to form strong relationships with institutions in other parts of Oceania, possibly hosting travelling exhibitions.

The previous developments could be starting points that could eventually increase the revenues of the Musee, allowing the institution to participate in art communities from the broader region of Oceania and more effectively addressing the interwoven histories of Oceanic people. In spite of its shortcomings, the Musee is not without potential, and its very uniqueness, and the fact that 
there are not already a significant number of existing exhibition sites in French Polynesia, could actually open up more possibilities than would outwardly seem likely. In these ways, the Musee Gauguin might engage more meaningfully-and secure a strong future role-with local communities, both indigenous and not, as well as visiting tourists interested in Gauguin's history. Even within appropriative and troubling representations there can be alternate, and counterhegemonic, ways of receiving these representations, and there are ways of mobilising pre-existing institutions to radically reconsider the representation of history, particularly the agency of indigenous cultures within situations of colonialism. By moving beyond a limited, and rather one-sided, representation of the past, and into a more dynamic model of heritage preservation and production, the Musee Gauguin might forge an active role as a heritage site that speaks to multiple communities, acknowledges that the needs of these communities are different, and actively engages contemporary art and culture. As Margaret Jolly writes in regard to museum representation in Oceania, 'There are differences in how "we" can be imaginedwhich derive from different sedimentations of the past and divergent contemporary coalitions of indigenous, settler, and migrant interests. These diverse articulations of roots and routes, though variable, are not totally contingent. They are constrained by the particularity of the ground of being-not just in the material sense of earth and ocean-but how that ground, that country, amply holds both connections and ruptures between pasts, presents, and futures.' [26] In striving to represent the contested, multilayered and interlocking histories that occupy contemporary Oceania, the Musee Gauguin might serve as a model for similarly troubled institutions in formerly (and currently) colonized places, speaking to the ability of heritage sites to transform with the histories of their locations.

\section{ACKNOWLEDGEMENTS}

I would like to thank Caroline Boyle-Turner, Tara Hiquily, Robert Koenig and Jonathan Reap for responding to my queries. Kristen Cheney and Jim Clifford read drafts of this essay in various forms; their comments significantly facilitated the development and articulation of my argument. My discussions with undergraduate students in my course 'Collecting Cultures: Histories of the Museum' at Appalachian State University in Spring 2007 encouraged me to re-think the literature on heritage as it applied to this particular site.

\section{NOTES}

[1] In his analysis of the rise of the museum in the post-Enlightenment west, Tony Bennett argues for the strong articulation between the museum and other 'exhibitionary complexes'-sites in which the experience of the subject is structured through architectural forms and shaped through the act of vision. See Bennett, 'The Exhibitionary Complex', 59-88.

[2] In 2006, a total of 221,549 tourists came to French Polynesia, for an average of 18,462 per month. Statistics from the Institut Statistique de Polynesie Franpise available at 
http://www.ispf.pf/(4mswbt55rzn3shrl Of03df55 )/index.aspx?choix=bref [accessed 8 October 2007]

[3] http://www. rssc.com/ships/ship.jsp?code=PAU [accessed 8 October 2007 ].

[4] http://www.moon.com/catalog2/tahiti.html [accessed 8 October 2007].

[5] In 'Maasai on the Lawn', Bruner and Kirshenblatt-Gimblett define 'tourist realism' as a form of virtual reality produced primarily through performance.

[6] MacClancy, 'Paradise Postponed', 428.

[7] The Gauguin Museum, n.p.

[8] The specific breakdown of visitors to French Polynesia by country of permanent residence sheds some light on the primary language spoken by these visitors. In 2006, approximately 33\% of visitors were from the United States; visitors from France comprised approximately $19 \%$ of visitors to French Polynesia. The third largest group of visitors, nearly 10\%, came from Japan. An additional $12 \%$ of visitors came from Australia, New Zealand or Great Britain. Statistics compiled by the Ministry of Tourism, French Polynesia, and made available courtesy of Jonathan Reap, Director of Communications, Tahiti Tourism North America.

[9] The Gauguin Museum, n.p.

[10] Ibid.

[11] Personal communication with Robert Koenig, Societe des Etudes Oceaniennes, June 2006, and Tara Hiquily, Musee de Tahiti et des nes, September 2007.

[12] See Teilhet-Fisk, Paradise Reviewed, and Childs, 'The Colonial Lens'. An early text in this literature is Danielsson, Gauguin in the South Seas. For more recent conversations on this topic, see also Clifford, 'Mahu', Dening, 'Performing on the Beaches of the Mind', Edmond, Representing the South Pacific, Jolly, 'Fraying Gauguin's Skirt', Teaiwa, 'Reading Gauguin's Noa Noa', and Wallace, Sexual Encounters.

[13] Spitz, 'Ou en Sommes-Nous ... ',101.

[14] Pineri, Introduction, 10.

[15] Waldroup, 'Traveling Images', 2004.

[16] See, for one example, Jim Vivieaere's mixed-media piece 6 Tahitians, 2 in Leningrad, 4 in Papeete, of 1990, reprinted in Thomas, Oceanic Art, figure 179.

[17] Transformations in Oceanic museum practice have global parallels. A number of national, and previously colonial, institutions have enacted substantial transformations in their policies and procedures around fhe retention, preservation and display of indigenous artefacts. This is a significant synthesis of an expansive discourse. See, among many others, Ames, Cannibal Tours and Glass Boxes, Bennett, Pasts Beyond Memory, Clifford, 'Looking Several Ways', 
Clifford, 'Museums as Contact Zones', Greenberg et al., Thinking about Exhibitions, Karp and Lavine, Exhibiting Cultures, Karp et al., Museums and Communities, Karp et al., Museum Frictions, Kirshenblatt-Gimblett, Destination Culture, Kreps, Liberating Culture, Macdonald, 'Collecting Practices', Macdonald, A Companion to Museum Studies, Macdonald and Fyfe, Theorizing Museums, Shelton, 'Museums and Anthropologies', Simpson, Making Representations, Witcomb, Re-imagining the Museum, and Vergo, The New Museology.

[18\} Mead, 'Indigenous Models of Museums in Oceania'.

[19] Fusitu' a, 'The Preservation of Cultural Property in Tonga', 198, 199.

[20] Again, this is a significantly synthesised discussion of a long and complex history. See Bolton, 'The Museum as Cultural Agent', Bolton, 'Resourcing Change', Cochrane, 'Out of the Doldrums', Eoe, 'The Role of Museums in the Pacific', Eoe and Swadling, Museums and Cultural Centres in the Pacific, Healy and Witcomb, South Pacific Museums, Jolly, 'On the Edge?', Lindstrom, 'Custom Remade', Losche, 'Memory, Violence and Representation', Mead, 'Indigenous Models of Museums in Oceania', Message, 'Contested Sites of Identity', Paulias, 'The Cultural Heritage of the Pacific', Regenvanu, Preface, Stanley, The Future of Indigenous Museums, Stevenson, 'The Museum as a Research Tool', and Vianney, 'The Vanuatu Cultural Centre'.

[21] See Stanley, 'Can Museums become Indigenous?'

[22] Kirshenblatt-Gimblett, Destination Culture, 7.

[23] Ibid., 7-8.

[24] See also Hoelscher, 'Heritage', and Macdonald, 'A People's Story'.

[25] In a similar way, anthropological and ethnographic museums in the West exist in complicated relationships with the cultures whose objects they've collected. See Kreps, Liberating Culture, 2.

[26] Jolly, 'On the Edge?', 455.

\section{REFERENCES}

Ames, M. Cannibal Tours and Glass Boxes: The Anthropology of Museums. 2nd edition. Vancouver: UBC Press, 1992.

Bennett, T. 'The Exhibitionary Complex'. In The Birth of the Museum: History, Theory, Politics, 59-88. London and New York: Routledge, 1995.

---. Pasts Beyond Memory: Evolution, Museums, Colonialism. London and New York: Routledge, 2004. 
Bolton, L. 'The Museum as Cultural Agent: The Vanuatu Cultural Centre Extension Worker Program'. In South Pacific Museums: Experiments in Culture, edited by C Healy and A. Witcomb, 13.1-13.13. Melbourne: Monash UniversityePress, DOI: 10.2104/spm 06013, 2006.

---. 'Resourcing Change: Fieldworkers, the Women's Culture Project and the Vanuatu Cultural Centre'. In The Future of Indigenous Museums: Perspectives from the Southwest Pacific, edited by N. Stanley, 23-37. New York and Oxford: Berghahn Books, 2007.

Bruner, E. and B. Kirshenblatt-Gimblett. 'Maasai on the Lawn: Tourist Realism in East Africa'. Cultural Anthropology 9, no. 4 (1994): 435-470.

Childs, E. 'The Colonial Lens: Gauguin, Primitivism, and Photography in the Fin de Siecle'. In Antimodernism and Artistic Experience: Policing the Boundaries of Modernity, edited by L. Jessup, 50-70. Toronto, Buffalo and London: University of Toronto Press, 2001.

Clifford, J. 'Looking Several Ways: Anthropology and Native Heritage in Alaska' . Current Anthropology 45, no. I (2004): 5-30.

---. 'The mahu goes native. Sexist or subversive? Gauguin's South Seas visions and renegade hybrid style'. London Times Literary Supplement, 7 November 1997: 3-4.

---. 'Museums as Contact Zones'. In Routes: Travel and Translation in the Late Twentieth Century. Cambridge, MA and London: Harvard University Press, 1997.

Cochrane, S. 'Out of the Doldrums: Museums and Cultural Centres in Pacific Islands Countries in the 1990s'. In Art and Performance in Oceania, edited by B. Craig, B. Kernot and C Anderson, 256-265. Honolulu: University of Hawai'i Press, 1999.

Danielsson, B. Gauguin in the South Seas. Translated by ReginaldSpink. London: George Allen and Unwin Ltd, 1965.

Dening, G. 'Performing on the Beaches of the Mind: An Essay'. History and Theory 41, no. 1 (2002): 1-24.

Edmond, R. Representing the South Pacific: Colonial Discourse from Cook to Gauguin. Cambridge, UK: Cambridge University Press, 1997.

Eoe, S. M. 'The Role of Museums in the Pacific: Change or Die'. In Museums and Cultural Centres in the Pacific, edited by S. M. Eoe and P. Swadling, 1-4. Port Moresby: Papua New Guinea National Museum, 1991.

---and P. Swadling, eds. Museums and Cultural Centres in the Pacific, Port Moresby: Papua New Guinea National Museum, 1991.

Fusitu'a, 'E. 'The Preservation of Cultural Property in Tonga'. In Museums and Cultural Centres in the Pacific, edited by S. M. Eoe and P. Swadling, 195-199. Port Moresby: Papua New Guinea National Museum, 1991.

The Gauguin Museum. Papeari, Tahiti: Gauguin Museum, 1984. 
Greenberg, R., B. Ferguson and S. Nairne, eds. Thinking about Exhibitions. London and New York: Routledge, 1996.

Healy, C and A. Witcomb, eds. South Pacific Museums: Experiments in Culture. Melbourne: Monash University ePress, 2006.

Hoelscher, S. 'Heritage'. In A Companion to Museum Studies, edited by S. Macdonald, 198-218. Malden, MA and London: Blackwell, 2006.

Jolly, M. 'Fraying Gauguin's Skirt: Gender, Race, and Liminality in the Pacific'. Pacific Studies 23 , no. $1 / 2$ (2000): 86-103.

---. 'On the Edge? Deserts, Oceans, Islands'. The Contemporary Pacific 13, no. 2 (2001),417466.

Karp, I. and S. Lavine, eds. Exhibiting Cultures: The Poetics and Politics of Museum Display. Washington: Smithsonian Institution Press, 1991.

---. C. M. Kreamer and S. Lavine, eds. Museums and Communities: the Politics of Public Culture. Washington: Smithsonian Institution Press, 1992.

---, C. A. Kratz, L. Szwaja and T. Ybarra-Frausto, eds. Museum Frictions: Public Cultures/Global Transformations. Durham, NC: Duke University Press, 2006.

Kirshenblatt-Gimblett, B. Destination Culture: Tourism, Museums, and Heritage. Berkeley: University of California Press, 1998.

Kreps, C. F. Liberating Culture: Cross-Cultural Perspectives on Museums, Curation, and Heritage Preservation. London and New York: Routledge, 2003.

Lindstrom, L. 'Custom Remade'. In The Cambridge History of the Pacific Islands, edited by D. Denoon et a!., 407-415. Cambridge, UK: Cambridge University Press, 1997.

Losche, D. 'Memory, Violence and Representation in the Tjibaou Cultural Centre, New Caledonia'. In The Future of Indigenous Museums: Perspectives from the Southwest Pacific, edited by N. Stanley, 70-77. New York and Oxford: Berghahn Books, 2007.

MacClancy, J. 'Paradise Postponed: The Predicaments of Tourism'. In Exotic No More: Anthropology on the Front Lines, edited by 1. MacClancy, 418-429. Chicago and London: University of Chicago Press, 2002.

Macdonald, S. 'Collecting Practices'. In A Companion to Museum Studies, edited by S. Macdonald, 81-97. London: Blackwell, 2006.

---. ed. A Companion to Museum Studies. London: Blackwell, 2006.

---. 'A People's Story: Heritage, Identity, and Authenticity'. In Touring Cultures: Transformations of Travel and Theory, edited by C. Rojek and J. Urry, 155-175. London: Routledge, 1997. 
--- and G. Fyfe, eds. Theorizing Museums: Representing Identity and Diversity in a Changing World. Cambridge, MA: Blackwell, 1996.

Mead, S. M. 'Indigenous Models of Museums in Oceania'. Museum 138 (1983): 98-101.

Message, K. 'Contested Sites of Identity and the Cult of the New'. In South Pacific Museums: Experiments in Culture, edited by C. Healy and A. Witcomb, 4.1-4.20. Melbourne: Monash University ePress, DOI: 10.2104/spm 06004, 2006.

Paulias, N. 'The Cultural Heritage in the Pacific: Preservation, Development, and Promotion'. In Museums and Cultural Centres in the Pacific, edited by S. M. Eoe and P. Swadling, 5-14. Port Moresby: Papua New Guinea National Museum, 1991.

Pineri, R. Introduction to Paul Gauguin, Heritage et Confrontations: Actes du Colloque de 6, 7, et 8 Mars 2003, I'Universite de la Polynesie Fran aise, 5-14. Paris: Motu, 2003.

Regenvanu, R. Preface to Vanuatu: Kunst aus der Sadsee, edited by C. Kaufmann, 9-11. Basel: Museum der Kulturen, 1997.

Shelton, A. A. 'Museums and Anthropologies: Practices and Narratives'. In A Companion to Museum Studies, edited by S. Macdonald, 64-80. London: Blackwell, 2006.

Simpson, M. Making Representations: Museums in the Post-Colonial Era. London and New York: Routledge, 2001.

Spitz, C. 'Oil en Sommes-Nous Cent Ans Apres La Question Posee par Gauguin, "D'oil VenonsNous? Que Sommes-Nous? Oil Allons-Nous?'" In Paul Gauguin, Heritage et Confrontations: Actes du Colloque de 6,7, et 8 Mars 2003, I'Universite de la Polynesie Fran aise, 100-107. Paris: Motu, 2003.

Stanley, N. 'Can Museums become Indigenous? The Asmat Museum of Culture and Progress and Contemporary Papua'. In The Future of Indigenous Museums: Perspectives from the Southwest Pacific, edited by N. Stanley, 190-204. New York and Oxford: Berghahn Books, 2007.

---. ed. The Future of Indigenous Museums: Perspectives from the Southwest Pacific. New York and Oxford: Berghahn Books, 2007.

Stevenson, K. 'The Museum as a Research Tool: A Tahitian Example'. In Artistic Heritage in a Changing Pacific, edited by P. Dark and R. Rose, 74-83. Honolulu: University of Hawaii Press, 1993. Intemlltiotlf11 Journal of Heritage Studies 505

Teaiwa, T. 'Reading Gauguin's Noa Noa with Hau'ofa's Nederends: "Militourism," Feminism, and the "Polynesian" Body'. The UTS Review 5, no. 1 (1999): 53-\{j9.

Teilhet-Fisk, J. Paradise Reviewed: An Interpretation of Gauguin's Polynesian Symbolism. Ann Arbor, MI: UMI Research Press, 1983.

Thomas, N. Oceanic Art. London: Thames and Hudson, 1995. 
Vergo, P., ed. The New Museology. London: Reaktion Books, 1989.

Wallace, L. Sexual Encounters: Pacific Texts, Modern Sexualities. Ithaca and London: Cornell University Press, 2003.

Vianney, A. 'The Vanuatu Cultural Centre'. In Museums and Cultural Centres in the Pacific, edited by S. M. Eoe and P. Swadling, 155-157. Port Moresby: Papua New Guinea National Museum, 1991.

Waldroup, H. 'Traveling Images: Representations of the South Pacific from Colonial and Postcolonial Worlds'. Ph.D. diss., University of California, Santa Cruz, 2004.

Witcomb, A. Re-imagining the Museum: Beyond the Mausoleum. London and New York: Routledge, 2003. 